\title{
Technology Applications in Czech Presidential Elections of 2013: A Story of Social Networks
}

\author{
Anna Matušková \\ Assistant Professor, Department of Marketing Communication and PR, Faculty of social sciences , \\ Charles University in Prague, Smetanovo nabr. 6, 11001 Praha 1, Prague, Czech Republic \\ Email: matuskova@fsv.cuni.cz \\ Wadim Strielkowski \\ Assistant Professor, Department of Marketing Communication and PR, Faculty of social sciences, \\ Charles University in Prague, Smetanovo nabr. 6, 11001 Praha 1, Prague, Czech Republic \\ Email: strielkowski@fsv.cuni.cz
}

\section{Doi:10.5901/mjss.2014.v5n21p419}

\section{Abstract}

This paper is concerned with the recent presidential elections in the Czech Republic and the use of social media in the presidential campaign. For the first time in the history of the independent Czech state the citizens were given the opportunity to elect the head of the state. Although the Czech political system allocates the president purely representative role, the struggle for power yielded nine qualified candidates and attracted wide mass media and public attention. What appeared to be of a special interest in the 2013 elections was the use of social networks (in particular Facebook) in presidential campaign of Karel Schwarzenberg, the current minister of Foreign Affairs. Although the social networks stood behind the unexpected victory of Schwarzenberg and secured him the place in the second round, they failed to gain enough support for the candidate in the second round of elections. We analyze the main distinguishable features of Karel Schwarzenberg's presidential campaign and the use of social networks by his electoral team and show that the excessive use of social media might lead to the exaggerated optimism and electoral failure.

Keywords: political campaigns, technology applications, presidential elections, social networks

\section{Introduction}

On the $25^{\text {th }}$ and $26^{\text {th }}$ of January 2013 , over 5 million Czech citizens went to the polls to give their vote to one of the two men aspiring to become the third president of the independent Czech Republic.

Most of the people in large cities as well as the younger part of the electorate (representing the generation $\mathrm{Y}$ ) was pretty sure that their candidate, the 75-year old current minister of Foreign Affairs Karel Schwarzenberg, whose surprisingly smooth and quite unexpected success in the first round of elections was attributed to the massive and welltargeted campaign that encompassed social media, selected mass media and well-organized public events. Karel Schwarzenberg positioned himself as the "true European", charismatic and flamboyant politician with a royalty background and connections in all possible places, which represented a remarkable contrast to the second candidate, Miloš Zeman, a former prime-minister of the Czech Republic (1998-2002) and a man associated with dubious scandals, political games and uneven standards.

Nevertheless, Zeman won the second round of the elections gaining $54.8 \%$ of the votes and beating Schwarzenberg by almost $10 \%$.

We presume that it was the overestimated role of social media, namely Facebook and Twitter that were extensively used in Schwarzenberg's presidential campaign that made his followers to believe in their superiority and led to his demise.

This paper is structured as follows. Section two presents the state of the art. Section three outlines our used methodology. Section four analyses the Schwarzenberg's election campaign and the use of Facebook and other social media for attracting the potential voters. Section five concludes with the discussion of results and some policy implications. 


\section{State of the Art: Social Media and Political Elections}

The use of social networks in political campaigns and elections is well-documented in the research literature. For instance, La Due Lake and Huckfeldt (2002) debated on the role of social capital and social networks in political participation. Pattie and Johnston (2002) analyzed context, conversation and conviction of social networks in the 1992 British general election, while Williams and Gulati (2007) described the role of social networks (with a special focus on Facebook) in America's 2006 midterm campaign and elections. More recently, McClurg (2006) examined disagreement and expertise effects in social networks on political participation, and Turdubaeva (2013) scrutinized communication with voters in social networks in the 2011 presidential elections in Kyrgyzstan.

While most of the research literature on political campaigns and elections is concerned with the Western political scene, there are also some studies focusing on elections and political systems in the former socialist countries of the Central and Eastern Europe (CEE) that for the most part became the members of the European Union (EU) in 2004 (see e.g. Millard, 2003; or Havlík and Vykoupilová, 2008). Szwed (2011) made an overview of printmedia poll reporting in Polish parliamentary campaigns of 1991-2007.

It has to be noted that social media are often related to political elections when the $Y$ generation is involved as the major group of voters. For instance, Jordaan and Surujlal (2013) studied the effects of mobile technology on generation $Y$ students who are the most "connected" generation with more than $60 \%$ of whom have access to the Internet through the desktop computers and more than $90 \%$ of whom own a cell phone that allows them to connect to the Internet.

The term "social network" was coined in 1954 when only few bold futurologists dreamed about the Internet. Barnes (1969a; 1969b) defined the "social network" as a social structure which included individuals or groups tied with the same type of activity, common interests, friendship or relationships.

Social networks might be useful in creating social ties and putting together the people of similar interests. Dodds et al. (2003) estimated that, depending on the separation of source and target, social searches can reach their targets in a median of five to seven steps. They concluded that although global social networks were searchable, actual success might largely depend on individual incentives.

The massive spread of Internet in the early 1990s and late 2000s lead to the spill of social networking to the cyberspace. Apart from e-mails and personal websites that enabled almost instant communication between people from all around the globe, Internet social networks gained special popularity and became a place for networking, socializing, gaming, business and commerce and other activities.

One of the most popular social networks is undoubtly Facebook. Since Facebook's spectacular launch in 2004, the site gained over 64 million active users in over four years of its existence. Facebook became the sixth-most trafficked site in the United States and it claims to add about 250000 new users per day (Facebook.com). The popularity of Facebook is reflected in high valuation assigned to the company which was estimated to be worth somewhere between $\$ 100$ million and \$15 billion US dollars (McGirt, 2007; Richards, 2008; Cohen, 2008).

Facebook is organized around linked personal profiles based on geographic, educational, or corporate networks (see e.g. Alemdar and Köker, 2013). Member profiles typically reveal a range of personal information, including favourite books, films, and music, e-mail addresses, personal websites, education and employment histories, relationship status (including a link to the profile of the person with whom one is involved), political views, and religion. Facebook users spend their time (an estimated average of 20 minutes per day) linking to friends' profiles, uploading and "tagging" friends in photos, creating and joining groups, posting events, website links, and videos, sending messages, and writing public notes on each other's Walls. Facebook can be viewed as an on-line communication platform that combines features of an e-mail, instant messaging, photo-sharing, and blogging programs, as well as a way to monitor one's friends' online social activity (Cohen, 2008).

\section{The Methodology and Strategy}

Karel's Schwarzenberg campaign was officially launched on October 24, 2012. The core team consisted of 20 people led by the campaign manager Marek Vocel. Sub-teams were created, including a strategic team, creative team, logistics team, scheduling team, events team, social media team and PR team. During the campaign, the team included 40 members who worked in cooperation with hundreds of volunteers.

The teams started to work in mid-August 2012 and from the very start it had to face various obstacles. The electoral law came with a few obligations including that in order for the candidates to be nominated, their accounts should be made be transparent, electoral committees should be in place, and some others.

The nomination process for party candidates whose parties were represented in Parliament differed from that of 
independent candidates. Schwarzenberg was a party candidate, so all he required for nomination were the signatures of MPs in his own party. Independent candidates had to collect 50,000 signatures. Many teams had thus been in action since summer 2012, gathering the necessary number of signatures. This created an interesting situation. The deadline for collecting signatures was the second week of November 2012, complicating polling, opposition research and timing because of the uncertainty as to who would run and who the chief opponent would be. It is clear that no professional campaign should develop its strategy in the absence of polling.

The campaign was divided into four phases (three as part of the first round and the fourth as part of the second round). The first phase was to introduce Schwarzenberg as a solid, genuine candidate. Polling showed that the media and the public did not consider him to be a proper candidate - he was perceived to be too old, not to be taking his candidacy seriously and as being distant from the electorate. Schwarzenberg hails from one of the oldest Czech-Austrian aristocratic families. His family had been forced to leave the country in 1948, so he had spent most of his life in Austria. He returned to the Czech Republic in 1990 after the Velvet Revolution, serving as Chancellor to President Václav Havel Havel was an exceedingly popular politician and Schwarzenberg was his close friend.

\section{Karel Schwarzenberg's Election Campaign: The Use of Social Media}

One characteristic feature of Karel Schwarzenberg's election campaign was the door-to-door initiative called "City-to-City, Village-to-Village". More than three hundred volunteers travelled across the country to promote their candidate. That number may look small, but it represented the largest grassroots campaign in the history of the country. Another project called entitled "Beer with Karel" which was also launched in support of the campaign, involved the candidate travelling across the country to visit cities to drink and talk with local people. The fact that many musicians and actors supported Schwarzenberg also played a substantial role. As an example, the team organized a "Clubbing with Karel" night in which popular music clubs featured bands playing to support Karel Schwarzenberg.

Another crucial factor was that of television debates. Their key role in the campaign deserved attention. Thus a significant chunk of time was organized to prepare for debates. The team organized media training sessions, keeping in mind a simple principle: always have your supporters visible on screen. More than ten large debates were held in the last week of the first round.

Another important change in the country was the fact that people openly supported presidential candidates. Schwarzenberg had a rather unique campaign symbol - he was depicted with a pink Mohawk. The well-known Czech artist David Černý, a close friend of the candidate known for controversial art, executed the image which was gradually moulded into a campaign symbol and was replicated on more than 20,000 badges and 5000 T-shirts worn by people all over the country. Apart from that, the campaign also had a more classic, conservative look, but somehow the pink and yellow image became its true symbol and won the hearts of Czech $\mathrm{Y}$ generation.

The first round of campaigning culminated in a huge concert in Prague. Many Czech popular musicians played. Also rounding things out was a television debate featuring all nine candidates, won by Schwarzenberg although each candidate ended up with less than five minutes of time.

24 hours before the election, four out of five major newspapers came out in open support of Schwarzenberg and his campaign flooded the country. He acquired 200,000 fans on Facebook, the highest number of any candidate (the winning candidate Miloš Zeman had less than 50,000 fans).

The first round was successful in Schwarzenberg came in second, with a difference of only 200,000 votes. Strategically, it was a huge success. From having been an underdog candidate, he was now a "dark horse".

However, the second round proved dramatically different. Miloš Zeman won by a 10-point margin. From this standpoint, the campaign was a great success thanks to the campaign strategy employed. But still, the candidate failed to win and the emotions reflected that result.

One should never underestimate the mood of the country and never cease analysing data or asking for feedback. One the decisive issue was that Mr. Schwarzenberg's opponent framed him as a foreigner. This should have come up in the pre-campaign analyses. The team underestimated the importance to voters of the fact that he had lived outside the country for 40 years. Another problem lay in the fact that the candidate could reach voters in large cities, leading the team to essentially isolate the campaign from the countryside. The campaign was trapped in the bubble of being the most successful online effort in the history of political campaigns in the Czech Republic.

\section{Conclusions and Discussions}

Overall, it appears that campaign strategy is a crucial part of election success. Karel Schwarzenberg's campaign had a 
peculiar and well-prepared plan that was divided into three phases with a heavy use of social media (in particular Facebook). When the candidate succeeded in the first round of the elections, a a fourth phase of the plan was initiated. Clearly, this did not culminate in a winning strategy, since the presidential candidate Zeman who did not rely upon social media and $Y$ generation won the elections. Nevertheless, when comparing the polls and the chances Karel Schwarzenberg had in the summer of 2012 to the final election results that became available to the general public in January 2013, one can state that the strategy based on the use of social network for engaging young voters was, in fact, very successful.

Karel Schwarzenberg's failure might be attributed to the fact that he and his political campaign advisers focused on partial tools and aspects of campaigning (e.g. employing the social media in order to attract mostly young people to the elections) and did not concentrate on the overall strategy of the presidential elections. The clear mission of the candidate, her or his purpose and the overall strategy are crucial for moulding the political campaign and achieving the pre-set goals.

\section{References}

Alemdar, M. Y., \& Köker, N. E. (2013). Facebook Use and Gratıfıcatıons: A Study Directed to Determining the Facebook Usage of Generations $X$ and $Y$ in Turkey. Mediterranean Journal of Social Sciences, 4(11), 238-249

Barnes, J. A. (1969a). Networks and political process. Social networks in urban situations, 51-76.

Barnes, J. A. (1969b). Graph theory and social networks: A technical comment on connectedness and connectivity. Sociology, 3(2), 215232.

Cohen, N. S. (2008). The valorization of surveillance: Towards a political economy of Facebook. Democratic Communiqué, 22(1), 5-22.

Cross, R. L., \& Parker, A. (2004). The hidden power of social networks: Understanding how work really gets done in organizations. Harvard Business Press.

Dodds, P. S., Muhamad, R., \& Watts, D. J. (2003). An experimental study of search in global social networks. science, 301(5634), 827829

Jordaan, D. B., \& Surujlal, J. (2013). Social Effects of Mobile Technology on Generation Y Students. Mediterranean Journal of Social Sciences, 4(11), 282-288

Ellison, N. B., Steinfield, C., \& Lampe, C. (2007). The benefits of Facebook "friends:" Social capital and college students' use of online social network sites. Journal of Computer-Mediated Communication, 12(4), 1143-1168.

Fletcher, D. (2010). How Facebook is redefining privacy. TIME Magazine, May.

Gibson, J. L. (2001). Social networks, civil society, and the prospects for consolidating Russia's democratic transition. American Journal of Political Science, 51-68.

Gonzales, A. L., \& Hancock, J. T. (2011). Mirror, mirror on my Facebook wall: Effects of exposure to Facebook on selfesteem. Cyberpsychology, Behavior, and Social Networking, 14(1-2), 79-83.

Havlík, V., \& Vykoupilová, H. (2008). Two dimensions of the Europeanization of election programs: The case of the Czech Republic. Communist and post-communist studies, 41(2), 163-187.

Hummon, N. P., \& Carley, K. (1993). Social networks as normal science*.Social Networks, 15(1), 71-106.

La Due Lake, R., \& Huckfeldt, R. (2002). Social capital, social networks, and political participation. Political Psychology, 19(3), 567-584.

Madge, C., Meek, J., Wellens, J., \& Hooley, T. (2009). Facebook, social integration and informal learning at university:'It is more for socialising and talking to friends about work than for actually doing work'. Learning, Media and Technology, 34(2), 141-155.

Memar, S., Adlipour, S., \& Khosravi, E. (2013). Sociological Analysis of the Relation Between the Uses of Virtual Social Networks and Life Style of the Young (Case Study of Facebook and the Young of Isfahan). Mediterranean Journal of Social Sciences, 4(6), 469-480

McClurg, S. D. (2006). The electoral relevance of political talk: Examining disagreement and expertise effects in social networks on political participation.American Journal of Political Science, 50(3), 737-754.

McGirt, Ellen. (2007). Hacker. Dropout. CEO. Fast Company, April.

Millard, F. (2003). Elections in Poland 2001: electoral manipulation and party upheaval. Communist and Post-Communist Studies, 36(1), 69-86.

Mitchell, J. C. (Ed.). (1969). Social networks in urban situations: Analyses of personal relationships in Central African towns. Humanities Press International.

Pattie, C., \& Johnston, R. (2002). Context, conversation and conviction: Social networks and voting at the 1992 British general election. Political Studies,47(5), 877-889.

Richards, Jonathan. (2008). Facebook's Financed Leaked. Times Online, February 1. Available at: http://technology.timesonline.co.uk Itol/news/tech_and_web/article3289054.ece (Accessed: 8.3.2013).

Skeels, M. M., \& Grudin, J. (2009, May). When social networks cross boundaries: a case study of workplace use of facebook and linkedin. InProceedings of the ACM 2009 international conference on Supporting group work (pp. 95-104). ACM.

Stanley, B. (2011). Populism, nationalism, or national populism? An analysis of Slovak voting behaviour at the 2010 parliamentary election. Communist and Post-Communist Studies, 44 (2), 257-270

Szwed, R. (2011). Printmedia poll reporting in Poland: Poll as news in Polish parliamentary campaigns, 1991-2007. Communist and Post-Communist Studies, 44(1), 63-72 
Turdubaeva, E. (2013). Communicating with Voters in Social Networks: The Case of 2011 Presidential Elections in Kyrgyzstan. Mediterranean Journal of Social Sciences, 4(9), 482-493

Vorvoreanu, M. (2009). Perceptions of corporations on Facebook: An analysis of Facebook social norms. Journal of New Communications Research, 4(1), 67-86.

Wellman, B. (2001). Computer networks as social networks. Science, 293(5537), 2031-2034.

Williams, C. B., \& Gulati, G. J. (2007, August). Social networks in political campaigns: Facebook and the 2006 midterm elections. In annual meeting of the American Political Science Association.

Yared, P. (2011). Facebook marketing: What doesn't work and what does. Webtrends White Paper. 
